EDITED BY ERICA CHARTERS MARIE HOULLEMARE, AND PETER H. WILSON
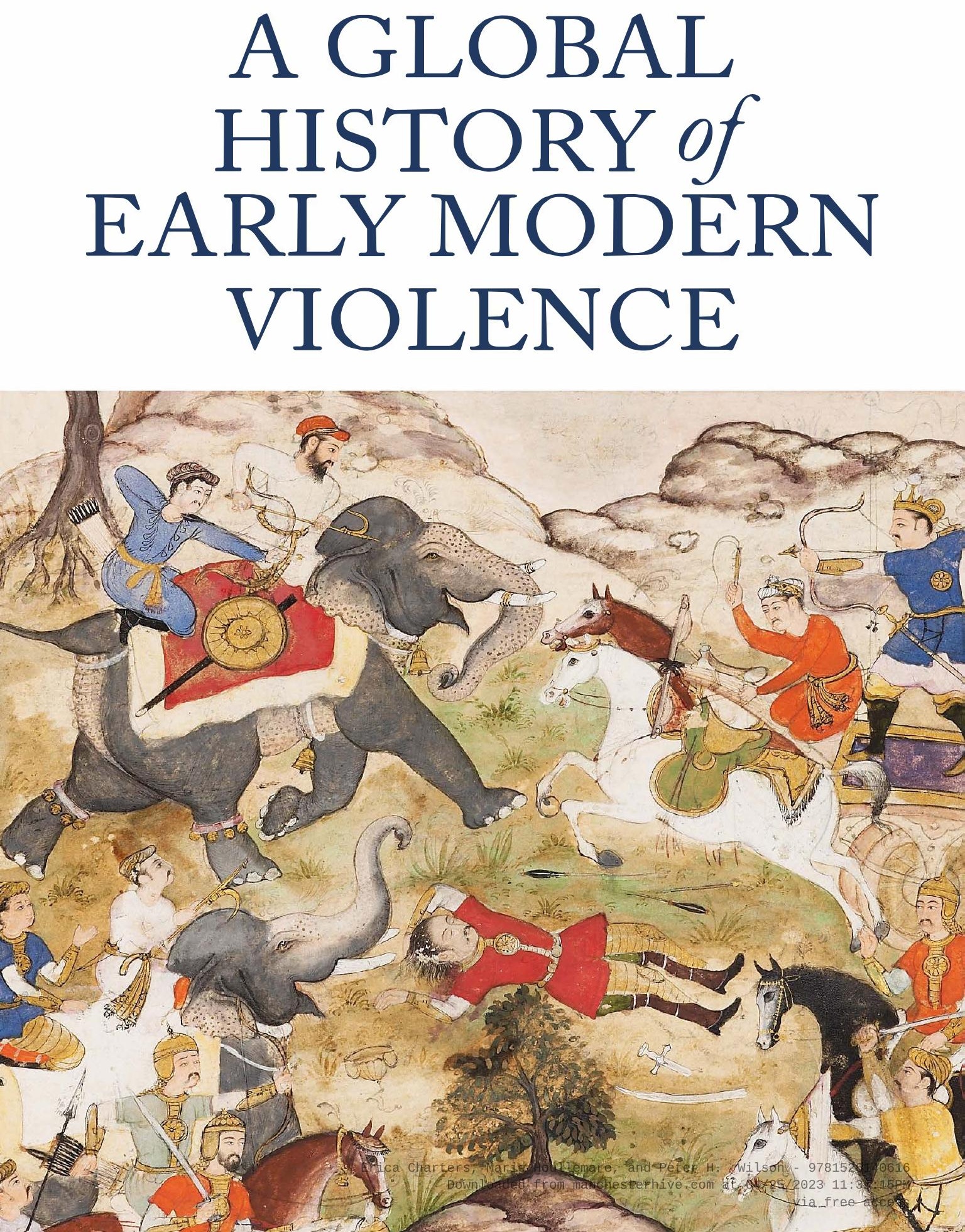


\section{A global history of early modern violence}

$\overline{\overline{ }}$

\section{MANCHESTER 1824}

Manchester University Press 
Erica Charters, Marie Houllemare, and Peter H. Wilson - 9781526140616 Downloaded from manchesterhive.com at 04/25/2023 11:35:15PM 


\title{
A global history of early modern violence
}

\author{
Edited by \\ Erica Charters, Marie Houllemare, \\ and Peter H. Wilson
}

Manchester University Press 
While copyright in the volume as a whole is vested in Manchester University Press, copyright in individual chapters belongs to their respective authors, and no chapter may be reproduced wholly or in part without the express permission in writing of both author and publisher.

This electronic version has been made available under a Creative Commons (CC-BY-NC-ND) licence, thanks to the support of Knowledge Unlatched, which permits non-commercial use, distribution and reproduction provided the author and Manchester University Press are fully cited and no modifications or adaptations are made. Details of the licence can be viewed at https://creativecommons.org/licenses/ by-nc-nd/4.0/

Published by Manchester University Press

Altrincham Street, Manchester M1 7JA

www.manchesteruniversitypress.co.uk

British Library Cataloguing-in-Publication Data

A catalogue record for this book is available from the British Library

ISBN 9781526140609 hardback

First published 2020

The publisher has no responsibility for the persistence or accuracy of URLs for any external or third-party internet websites referred to in this book, and does not guarantee that any content on such websites is, or will remain, accurate or appropriate.

Cover credit: Mohan, Son of Banwari, 'The Pandava brothers do battle with the King of Anga'. Image (C) Ashmolean Museum, University of Oxford

Cover design: Abbey Akanbi, Manchester University Press

Typeset by

Servis Filmsetting Ltd, Stockport, Cheshire

Erica Charters, Marie Houllemare, and Peter H. Wilson - 9781526140616 